УДК 343.98

DOI https: / / doi.org/10.32837 / yuv.v0i2.1729

\title{
I. Гришко,
}

аспірантка кафедри криміналістики

Національного юридичного університету імені Ярослава Мудрого

\section{ФУНКЦІОНАЛЬНЕ ПРИЗНАЧЕННЯ ТАКТИЧНИХ ОПЕРАЦІЙ ПІД ЧАС РОЗСЛІДУВАННЯ САМОВІЛЬНОГО ЗАЙНЯТТЯ ЗЕМЕЛЬНОЇ ДІЛЯНКИ ТА САМОВІЛЬНОГО БУДІВНИЦТВА}

Здатність тактичних операцій до глибокого проникнення у криміналістичну сутність злочинних проявів і пристосовування до умов різноманітних слідчих ситуацій [1, с. 116] сприяє розширенню можливостей їх практичного використання слідчими як найбільш оптимального засобу реалізації методів досудового розслідування. Разом із тим створення (розроблення) i пропонування до застосування нових тактичних операцій викликані модернізацією злочинності [2, с. 174] та неможливі без осмислення функціонального призначення цього тактичного засобу в контексті криміналістичної методики розслідування конкретного злочину, а саме самовільного зайняття земельної ділянки та самовільного будівництва.

Передусім для цього усвідомлення потрібно мати чітке уявлення, що тактична операція - це функціональна система, яка орієнтована на досягнення певної мети та призначена для виконання певних функцій [3, с. 27], що вказує на іiі спрямування ефективно вирішувати окремі тактичні завдання, зумовлені слідчими ситуаціями, що виникають під час самовільного зайняття земельної ділянки та самовільного будівництва. Викладене зайвий раз засвідчує, що тактичні операції $€$ важливими засобами через їх функціональну спрямованість, оскільки процес розслідування злочинів у сфері земельних відносин, до яких належить самовільне зайняття земельної ділянки та самовільне будівництво, характеризується підвищеною складністю [4, с. 151]. Отже, сьогодні серед досліджень теоретичних і практичних проблем розслідування самовільного зайняття земельної ділянки та самовільного будівництва викликає певний науковий інтерес 3'ясування функціонального призначення тактичних операцій у рамках розслідування цього злочину.

Більше того, проблематика функціонального призначення тактичних операцій у процесі розслідування самовільного зайняття земельної ділянки та самовільного будівництва у криміналістичній доктрині та слідчій практиці є актуальною та значимою, адже в умовах сьогодення залишається не розробленою. Варто зауважити, що, будучи відображенням реального процесу функціонування тактичних операцій, функціональне призначення, як правило, віддзеркалюється у функціях цього тактичного засобу розслідування. Зазначене $є$ цілком очевидним, оскільки у функціях тактичних операцій виражається ії сутність - найбільш глибинне й усталене в ній. Окрім того, функції тактичних операцій характеризують призначення цього тактичного засобу, визначають характер та його особливості як самостійного виду практичної пізнавально-пошукової діяльності. Водночас висвітлення функціонального призначення тактичних операцій через перелік вузького кола їхніх функцій або функціональних властивостей 
без глибокого теоретичного розроблення не дає повного уявлення про правильне розуміння природи, сутності функцій тактичних операцій у слідчій діяльності [5, с. 161].

Дослідження багатогранних функцій тактичних операцій $€$ найбільш перспективним напрямом розроблення концепції цих тактичних засобів у криміналістиці [6, с. 45]. Разом із тим уніфікація поглядів на функції тактичних операцій, формування їх системи дає можливість правильно визначити напрями і зміст усіх подальших досліджень [7, с. 9]. Тому, враховуючи вищевикладене, пріоритетним напрямом наукового дослідження є з'ясування кола діяльності тактичних операцій, визначення прояву їхніх властивостей, іншими словами, функціонального призначення у контексті розслідування самовільного зайняття земельної ділянки та самовільного будівництва.

У спеціальній криміналістичній літературі зазначається, що тактичні операції з позицій функціонального призначення науковці розглядають як: 1) засіб реалізаціі методів розслідування; 2) найбільш раціональну форму використання сил і засобів правоохоронних органів; 3 ) організаційний і тактичний засіб усунення протидії з боку правопорушників; 4) не тільки засіб, а й процедуру вирішення конкретного тактичного завдання; 5) засіб забезпечення найбільш ефективних результатів зі збирання доказів і оперування ними тощо [8, с. 25]. Зазначені положення, на нашу думку, не є вичерпними способами пізнання функціонального призначення тактичних операцій, оскільки поглиблене уявлення щодо останніх видається можливим ще й крізь дослідження їхніх функцій.

Так, указане цілком є цілком доречним, оскільки під функціями тактичних операцій слід розуміти систему властивостей, що відбивають і зумовлюють роль і призначення цього тактичного засобу для оптимізації процесу досудового розслідування і вирішення тактичних (проміжних) завдань щодо певних слідчих ситуацій зокрема [9, с. 129]. У цьому аспекті В.Ю. Шепітько, розглядаючи функції тактичних прийомів, зауважив, що дослідження функціонального призначення цього тактичного засобу вимагає розгляду специфіки загальних і окремих функцій [10, с. 64]. Виходячи з викладеного, одним із нагальних завдань теоретичного розроблення проблематики функціонального призначення $€$ дослідження функцій тактичних операцій.

Разом із тим у теорії криміналістики існують різні погляди щодо виокремлення функцій цього тактичного засобу розслідування. На думку I.M. Комарова, криміналістичні операції виконують інформаційно-пізнавальну, конструктивну, організаційну та регулятивну функції [11, с. 88]. Зокрема, В.Ю. Шепітько вказує, що тактичні операції за характером спрямованості поділяють на пізнавальні, пошукові та організаційні [12, с. 41-44]. На нашу думку, зазначені функції тактичних операцій відображають досить розгалужену систему властивостей цього тактичного засобу розслідування і відображають основні напрями діяльності у ході реалізації тактичних операцій.

Окрім того, викликає певний науковий інтерес поділ функції тактичних операцій на внутрішні та зовнішні [6, с. 17-22]. Розглядаючи внутрішні функції, слід зазначити, що вони регулюють процеси, які відбуваються всередині побудови тактичних операцій. Різновидами внутрішніх функцій тактичних операцій, можуть бути такі: 1) узгоджувальна; 2) субординаційна; 3) регулятивна; 4) оптимізуюча; 5) цілеполягальна. Своєю чергою, зовнішні функції забезпечують зовнішні результати реалізації тактичної операції, вплив на слідчу ситуацію 3 метою зміни на краще або вирішення взагалі. Указані функції мають досить розгалужену систему підстав класифікації, серед яких виділяють: 1) за ступенем узагальнення (загальні, окремі); 2) за обсягом функцій (основні, додаткові); 3) за складом функцій (прості, складні); 
4) за змістом функцій (цільові, рольові) тощо [9, с. 131-134].

Незважаючи на існування у криміналістичній доктрині багатоманітних підходів до трактування функцій тактичних операцій, пізнання сутності функціонального призначення цього засобу розслідування у контексті розглядуваного злочину забезпечить поглиблене дослідження функцій діяльнісної спрямованості. У цьому сенсі маємо на увазі, що реалізація тактичних операцій передбачає визначення основних напрямів діяльності, ролі та призначення цього тактичного засобу під час розслідування самовільного зайняття земельної ділянки та самовільного будівництва. Щодо останнього положення, то, дійсно, тактична операція $€$ відносно самостійною специфічною структурою діяльнісного типу [13, с. 79] або виступає засобом діяльності слідчого, який застосовується для вирішення тактичних завдань, що виникають під час розкриття, розслідування і попередження злочинів [14, с. 81-82].

Розвиваючи цю думку, функціональне призначення тактичних операцій у розслідуванні самовільного зайняття земельної ділянки та самовільного будівництва виявляється у контексті основних, базових функцій. До такого висновку нам удалося дійти, враховуючи висловлену В.Ю. Шепітьком позицію, який під час дослідження тактичних прийомів як функції цього тактичного засобу виділяє такі: 1) пізнавальну; 2) прогностичну; 3) комунікативну; 4) регулятивну [10, с. 64-68]. Разом із тим, підтримуючи висловлений підхід та спираючись на сформовану В.М. Шевчуком систему діяльнісних (базових) функцій, можемо зазначити, що функціональне призначення тактичних операцій під час розслідування самовільного зайняття земельної ділянки та самовільного будівництва варто розглядати 3 огляду на функції діяльнісної спрямованості, а саме: 1) пізнавальної; 2) прогностичної; 3) регулятивної; 4) організаційної; 5) конструктив- ної; 6) пошукової; 7) профілактичної [15, с. 240-249; 16, с. 202-213; 17 , с. 38-48]. У цьому аспекті вважаємо, що аргументація особливої значимості цих функцій, породжує потребу ï детального дослідження виходячи зі специфіки та особливостей самовільного зайняття земельної ділянки та самовільного будівництва.

Пізнавальна - полягає у тому, що тактичні операції виступають засобом пізнання події злочину [18, с. 74-76], як видається, зазначене положення найбільш влучно відображає сенс цієї функції. Разом із тим наведене судження цілком виправдане, адже під час розслідування самовільного зайняття земельної ділянки та самовільного будівництва слідчий має мінімальну кількість даних про обставини вчиненого діяння, а тому пізнавальна функція тактичних операцій забезпечує отримання різноманітної інформації, що має значення для встановлення обставин злочинної подіi. Беручи до уваги наведене, приєднуємося до думки, що розслідування злочинів шляхом проведення тактичних операцій як пізнавальна діяльність повинна забезпечувати досягнення істини [19, с. 85], що є найбільш важливим завданням досудового слідства. Виходячи $з$ наведеного, можна стверджувати, що особливість пізнавальної функції полягає у розумовій діяльності слідчого зі збору та обробки інформації за допомогою використання тактичних операцій. Саме такий підхід створює перспективи та умови для всебічного дослідження й осмислення обставин самовільного зайняття земельної ділянки та самовільного будівництва.

При цьому у сучасних умовах і реаліях розслідування самовільного зайняття земельної ділянки та самовільного будівництва слідчий отримує інформацію з таких джерел: 1) інформація надійшла від власника чи користувача земельної ділянки; 2) інформація надійшла від органів, які контролюють діяльність у сфері земельних відносин та будівництва (працівників органів державної влади та місцевого самоврядування); 3) інфор- 
мація про виявлений факт самовільного зайняття земельної ділянки та самовільного будівництва була зібрана оперативними підрозділами Національної поліції України; 4) факт учинення самовільного зайняття земельної ділянки та самовільного будівництва був виявлений у ході розслідування іншого злочину; 5) факт самовільного зайняття земельної ділянки та самовільного будівництва був висвітлений у ЗMI та набув широкого розголосу серед населення [20, с. 59]. Водночас пізнавальна діяльність слідчого складається не лише 3 виявлення (отримання) інформації, яка міститься в носіях, а й 3 ї сприйняття 3 метою розуміння та засвоєння [21, с. 74$]$.

Важливо враховувати, що пізнавальна діяльність слідчого під час розслідування самовільного зайняття земельної ділянки та самовільного будівництва спрямовується на з'ясування обставини, які, своєю чергою, зумовлюють вибір найбільш оптимальних тактичних операцій. У спеціальній літературі до подій, які потребують установлення, належать: 1) факт зайняття встановленою або невстановленою особою (особами) земельної ділянки, яка має певне місце розташування та площу в складі однієї 3 категорій земель; 2) правова належність цієї земельної ділянки певній фізичній чи юридичній особі, державі; 3) відсутність правових підстав для розпорядження земельною ділянкою у особи (осіб), яка їі зайняла (тобто факт самовільності захоплення); 4) значний розмір шкоди, завданої законному володільцю або власнику земельної ділянки [22, с. 71]. Викладене зайвий раз засвідчує, що тактичні операції виконують пізнавальну функцію з урахуванням специфіки та особливостей, притаманних самовільному зайняттю земельної ділянки та самовільному будівництву, i, як наслідок, дають змогу отримувати необхідну доказову інформацію за рахунок осмислення, пізнання події минулого.

Прогностична - сутність цієї функції тактичних операцій полягає у можливості передбачити: 1) розвиток слідчої ситуаціі; 2) процес вирішення тактичних завдань; 3) збір та накопичення інформації з урахуванням детермінуючих чинників тощо. Саме цим і визначається правильний вибір слідчих (розшукових) дій, інших процесуальних дій, організаційно-технічних та інших заходів, спрямованих на оптимізацію досудового розслідування самовільного зайняття земельної ділянки та самовільного будівництва. Щодо висловлених суджень, то у криміналістиці прогностична функція сприяє виробленню прогнозів, моделей, довгострокового планування діяльності, розробленню іiі стратегії та тактики [23, с. 121].

Окрім цього, висловлюється думка, що прогнозування у загальній формі $є$ уявленням про можливе змінення слідчої ситуації, іï окремих компонентів, що, природно, вимагає від слідчого адекватного реагування [24, с. 160]. Досліджуючи тактичні прийоми, В.Ю. Шепітько вказує, що прогностична функція охоплює три основні напрями передбачення: 1) власних дій слідчим; 2) дій інших учасників процесу розслідування; 3) можливості управління здійснюваною діяльністю [10, с. 65]. Беручи до уваги специфіку та складність розслідування самовільного зайняття земельної ділянки та самовільного будівництва, варто зазначити, що логічне планування $€$ одним із пріоритетних завдань, що постають перед слідчими.

Підтримуємо позицію В.А. Журавля, який указує, що реалізація криміналістичних прогнозів у судово-слідчій i оперативно-розшуковій діяльності спрямована на оптимізацію планування та організації процесу розслідування, підвищення ефективності слідчих дій i оперативно-розшукових заходів [25, с. 160]. Своєю чергою, слід зазначити, що прогностична функція тактичних операцій під час розслідування самовільного зайняття земельної ділянки та самовільного будівництва сприяє мінімізації ризиків, передбачає можливі негативні наслідки і стимулює заздалегідь слідчих до розроблення заходів уникнення чи ліквідації нега- 
тивних обставин шляхом вибору оптимальних тактичних операцій.

Регулятивна - функція, яка відображає тактичні операції як специфічний тактичний засіб регулювання слідчої ситуації у процесі розслідування самовільного зайняття земельної ділянки та самовільного будівництва. Очевидно, що у цьому разі регулятивна функція сприяє оптимальному вирішенню тактичного завдання і впливу на слідчу ситуацію, що досягається організацією 3 провадження слідчих дій, оперативно-розшукових заходів тощо [26, с. 119]. Виходячи із цього, контроль та зміна слідчої ситуації у потрібному напрямі під час розслідування самовільного зайняття земельної ділянки та самовільного будівництва відбуваються завдяки регулятивній функції тактичних операцій, яка вдало оптимізує цей процес.

Головний iі сенс полягає у тому, що під час реалізації логічно спланованих тактичних операцій суб'єктами досудового розслідування відбувається зміна слідчої ситуації, яку вони регулюють. При цьому особливість слідчих ситуацій самовільного зайняття земельної ділянки та самовільного будівництва проявляється як сукупність умов, в яких відбувається розслідування, і характеризується встановленням незаконних операцій із землею, що зумовлює проведення певних слідчих (розшукових) та негласних слідчих (розшукових дій) [27, с. 129-130]. У даному разі йдеться про негативні наслідки фактичної безкарності, яка призвела до того, що земельну ділянку стало простіше і вигідніше самовільно зайняти і тривалий час безоплатно використовувати, ніж оформляти права на неї. Тобто особа при цьому самовільно, без жодних правових підстав займає земельну ділянку і протиправно ї̈ використовує [28, с. 3]. А тому вказане цілком підтверджує факт того, що розглядуваний злочин характеризується антисуспільною спрямованістю, і, як наслідок, специфіка слідчих ситуацій під час розслідування цього злочину має підвищену складність, відрізняється несприятливим характером та потребує постійного коригування слідчими.

Організаційна - організаційна спрямованість тактичних операцій визначається передусім природою цих засобів, які апріорі передбачають провадження не однієї слідчої (судової) дії чи заходу, а цілого їх комплексу, що наперед визначає необхідність реалізації організаційно-управлінських підходів із метою визначення оптимальної послідовності, своєчасності, узгодженості провадження окремих компонентів операції [29, с. 57]. Реалізація цієї функції під час розслідування самовільного зайняття земельної ділянки та самовільного будівництва відображається у плануванні послідовності проведення тактичних операцій, їх побудови з урахуванням специфіки слідчої ситуації, кола учасників, обстановки вчинення злочину тощо.

Зокрема, переконливою $є$ думка В.О. Коновалової, що природа розслідування злочину припускає як необхідну передумову власної організації поєднання слідчих та оперативно-розшукових дій, оскільки одних зусиль слідчих органів не завжди достатньо для вирішення безлічі завдань, пов'язаних із розкриттям злочинів [30, с. $15-16]$. $\mathrm{Ha}$ нашу думку, такий підхід повно й точно відображає специфіку сучасних реалій розслідування самовільного зайняття земельної ділянки та самовільного будівництва, оскільки розрізнені слідчі дії переважно є неефективними, а тому потрібна упорядкована сукупність елементів для забезпечення реалізації тактичної операції. При цьому В.Ю. Шепітько та В.А. Журавель розглядають тактичні операції як організаційно-тактичний засіб. На їхню думку, організаційні засади означають оптимальне взаєморозташування і взаємозв'язок елементів певного комплексу, провадження яких зумовлене єдиною метою та здійснюється в певних умовах місця і часу [31, с. 186]. Окрім того, організаційна функція проявляється й у взаємодії суб'єктів досудового розслідування 
3 іншими учасниками кримінального провадження, такими як експерти, свідки, співробітники правоохоронних органів тощо.

Конструктивна - основна суть цієї функції у процесі розслідування самовільного зайняття земельної ділянки та самовільного будівництва полягає у можливості створення в результаті планування уявної моделі майбутньої діяльності 3 розслідування злочинів, елементами якої $€$ комплекси слідчих (розшукових) дій, негласних слідчих (розшукових) дій, оперативно-розшукових, превентивних та інших заходів. Указана уявна модель фіксується у плані розслідування, інших допоміжних матеріалах (схемах, графіках та ін.) і конкретизується у плані проведення тактичної операції [9, с. 143].

При цьому конструктивна функція тактичних операцій сприяє вибору правильного напряму розслідування самовільного зайняття земельної ділянки та самовільного будівництва, забезпечує вирішення тактичних завдань, висунення та перевірку версій за допомогою раціонально вибраних тактичних операцій. Визначити напрям розслідування означає визначити комплекс дій, які є необхідними й оптимальними для встановлення обставин, пов'язаних із подією злочину [32, с. 174]. Слід зазначити, що висунення типових версій потребує їх перевірки. Як наслідок, перевірка версій становить зміст планування розслідування, яке має суттєве значення для успішного вирішення завдань у кримінальних справах щодо злочинів у сфері земельних відносин, до яких належать і самовільне зайняття земельної ділянки та самовільне будівництво. При цьому у письмовому плані розслідування злочинів у сфері земельних відносин доцільно відображати такі елементи: 1) слідчі версіі; 2) обставини, що вимагають з'ясування; 3) слідчі дії та оперативно-розшукові заходи; 4) термін виконання; 5) виконавці; 6) примітки [33, с. 241-242]. Таким чином, наявність плану дає змогу слідчому більш цілеспрямовано проконтролювати хід розслідування, проведення тактичних операцій [34, с. 103-104], що є необхідним для досягнення поставлених цілей під час розслідування цього злочину.

Пошукова - в основі цієї функції лежить пошукова діяльність як організація та ведення пошуків із метою виявлення об'єктів, місцезнаходження яких невідомо [9, с. $145 ; 17$, с. 38-48]. У процесі розслідування самовільного зайняття земельної ділянки та самовільного будівництва зазначена функція тактичних операцій дає змогу вибирати найбільш ефективні засоби та методи проведення пошукових дій для виявлення невідомих об'єктів. Розглядаючи пошукову функцію тактичних операцій, у спеціальній літературі зазначається, що під час розслідування самовільного зайняття земельної ділянки та самовільного будівництва об'єктами пошуку є: 1) особи; 2) документи; 3) речі. При цьому особливості технологій учинення цього злочину, а також головне значення документів у механізмі слідоутворення свідчать про можливість виокремлення типової тактичної операції «Документ». У контексті розслідування цього злочину зміст указаної операції полягає у комплексі заходів, спрямованих на пошук та збереження документів, у яких відображено важливі для кримінального провадження дані [4, с. 152].

При цьому треба враховувати, що пошукова функція має психологічну основу, пов'язану із закономірностями психології приховування і психології відшукування, використання рефлексивного мислення й управління [35, с. 144-156]. $\mathrm{y}$ цьому аспекті для злочинів у сфері земельних відносин, у тому числі самовільного зайняття земельної ділянки та самовільного будівництва, характерним $€$ те, що поведінка суб'єкта після вчинення злочину загалом представлена діями приховування слідів злочину, виявляється переважно в мінімальних діях зі знищення відповідних документів, формальних діях з усунення заподіяної шкоди тощо [36, с. 122]. 
Розвиваючи вказану думку, під час реалізації пошукової функції тактичних операцій, спрямовану на виявлення шуканого, потрібно враховувати особливості приховування, що характерні для цього злочину. У зв'язку із цим положення спеціальної літератури вказують, що серед типових способів приховування, що можуть бути використані злочинцем після самовільного зайняття земельної ділянки та самовільного будівництва, насамперед потрібно назвати: 1) заходи, спрямовані на вироблення документів, що засвідчують право власності на земельну ділянку; 2) вироблення відповідних дозволів на будівництво вже після іï зайняття чи початку проведення будівельних робіт; 3) заяву про втрату частини документів, що підтверджують відповідне право на землю чи дозвіл на будівництво; 4) спрямування безпідставних скарг у відповідні інстанції на власника земельної ділянки; 5) передання незаконно зайнятої земельної ділянки третім особам нібито на законних підставах; 6) включення власника земельної ділянки до членів фермерських господарств [20, с. 50]. Таким чином, пошукова функція тактичних операцій у досудовому розслідуванні полягає у виконанні слідчим розумово-пошукових завдань, спрямованих на встановлення об'єктивної істини у кримінальному провадженні.

Профілактична - функція тактичних операцій, яка полягає, головним чином, у профілактичній діяльності слідчого $з$ приводу виявлення обставин, що стають передумовами вчинення самовільного зайняття земельної ділянки та самовільного будівництва, а також ужитті заходів щодо їх усунення. Разом із тим необхідно враховувати, що виокремлення тактичних операцій профілактичної спрямованості та їх проведення в ході розслідування злочинів сприяють досягненню загальних цілей профілактичної діяльності слідчого [37, с. 59-69]. На наше переконання, під час розслідування самовільного зайняття земельної ділянки та самовільного будівництва слідчими повинні проводитися тактичні операції, які спрямовані на профілактику, до яких належить: 1) виявлення злочинів, що готуються; 2) ужиття всіх необхідних заходів щодо запобігання можливому злочину; 3) встановлення причин та умов, що сприяють учиненню цього злочину.

Розглядаючи виявлення причин та умов, а також можливості прийняття заходів усунення злочинного прояву самовільного зайняття земельної ділянки та самовільного будівництва, варто звернути увагу, що криміналістична профілактика злочинів як специфічна діяльність уповноважених законом суб'єктів здійснюється на підставі застосування засобів криміналістичної техніки, прийомів, криміналістичної тактики, методів розслідування певних злочинів і пов'язана з установленням причин та умов, що сприяють учиненню злочинів, а також ужиття спеціальних криміналістичних засобів для профілактики, запобігання і припинення злочинної діяльності конкретних осіб [38, с. 175-176].

Таким чином, функціональне призначення тактичних операцій під час розслідування самовільного зайняття земельної ділянки та самовільного будівництва - це відображення тактичних операцій через систему властивостей як надійного засобу організації, оптимізації, підвищення ефективності розслідування з метою впливу на слідчу ситуацію для іï зміни у сприятливий бік і вирішення конкретних тактичних завдань цього злочину.

Виходячи 3 викладеного, зміна структури й характеру протиправних посягань, підвищення активізації протидії розслідуванню злочинних проявів, зокрема самовільного зайняття земельної ділянки та самовільного будівництва, потребують широкого запровадження у практику слідчої діяльності ефективних комплексних засобів боротьби, a саме тактичних операцій. Разом із тим реалізація тактичних операцій пов'язана $з$ осмисленням властивостей 
цього тактичного засобу, які вказують на його роль у рамках розслідування конкретного злочину, тобто визначення функціонального призначення.

Отже, проведене дослідження дало змогу дійти висновку, що функціональне призначення слід розглядати як сукупність взаємопов'язаних функцій, які відображають основні аспекти і напрями проведення тактичних операцій, орієнтовані на вирішення тактичних завдань, при цьому забезпечуючи ефективність, оптимізацію розслідування самовільного зайняття земельної ділянки та самовільного будівництва у цілому.

Статтю присвячено дослідженню функиіонального призначення тактичних операцій під час розслідування самовільного зайняття земельної ділянки та самовільного будівництва. Запропоновано розглядати функиіональне призначення тактичних операцій під час розслідування вказаного злочину як сукупність взаємопов'язаних функиій, оскільки під функиіями тактичних операцій слід розуміти систему властивостей, щуо відбивають $і$ зумовлюють роль та призначення изього тактичного засобу для оптимізації процесу досудового розслідування $i$ вирішення тактичних завдань щодо певних слідчих ситуаизіи. Проведено аналіз наукових підходів до проблем визначення функиій тактичних операцій, висловлено авторське бачення иієї проблематики. Обтрунтовано, щзо пізнання сутності функціонального призначення тактичних операцій під час розслідування самовільного зайняття земельної ділянки та самовільного будівництва забезпечить поглиблене дослідження функцій діяльнісної спрямованості. Визначено, щзо до функиій діяльнісної спрямованості тактичних операцій можна віднести: пізнавальну; прогностичну; регулятивну; організаційну; конструктивну; пошукову; профілак- тичну. Запропоновано функиіональне призначення тактичних операцій під час розслідування самовільного зайняття земельної ділянки та самовільного будівництва розглядати як відображення ичх тактичних засобів через систему властивостей як надійного засобу організації, оптимізаціі, підвищення ефективності розслідування з метою впливу на слідчу ситуацію для ї зміни у сприятливий бік $і$ вирішення конкретних тактичних завдань цього злочину. Розглянуто специфіку формування та реалізації тактичних операцій під час розслідування самовільного зайняття земельної ділянки та самовільного будівництва у контексті розглядуваних функиій. Визначено перспективні напрями подальших досліджень указаної проблематики.

Ключові слова: розслідування самовільного зайняття земельної ділянки та самовільного будівництва, функціі тактичних операцій, тактичні засоби розслідування, роль та призначення тактичних операцій, тактичні операції.

Hryshko I. Functional purpose of tactical operations in investigating unauthorized occupation of land and unauthorized construction

The article is devoted to the research of the functional purpose of tactical operations in the investigation of unauthorized occupation of land and unauthorized construction. It is proposed to consider the functional purpose of tactical operations in the investigation of this crime as a set of interrelated functions, as the functions of tactical operations should be understood as a system of properties that reflect and determine the role and purpose of this tactical tool to optimize the process of pre-trial investigation in this situations. The analysis of scientific approaches to problems of definition of functions of tactical operations is carried out, the author's vision of this problem is expressed. It is substantiated that the knowledge of 
the essence of the functional purpose of tactical operations in the investigation of unauthorized occupation of land and unauthorized construction will provide an in-depth study of the functions of activity orientation. It is determined that the functions of activity orientation of tactical operations include: cognitive; prognostic; regulatory; organizational; constructive; search engine; preventive. It is proposed to consider the functional purpose of tactical operations in the investigation of unauthorized occupation of land and unauthorized construction as a reflection of these tactical means through the system of properties, as a reliable means of organization, optimization, efficiency of investigation, in order to influence of the investigation situation and solution tactical tasks of this crime. The specifics of formation and implementation of tactical operations in the investigation of unauthorized occupation of land and unauthorized construction, in the context of the considered functions are considered. Perspective directions of further researches of the specified problems are defined.

Key words: investigation of unauthorized occupation of land and unauthorized construction, functions of tactical operations, tactical means of investigation, role and purpose of tactical operations, tactical operations.

\section{Література}

1. Князев В.А. О понятии и классификации тактических задач расследования преступлений. Проблемь социалистической законности. 1991. Bып. 25. С. 116-119.

2. Шепітько В.Ю. Засоби криміналістичної тактики в діяльності органів досудового слідства (проблеми ефективності застосування). Правові засади підвищення ефективності боротьби зі злочинністю в Україні : матеріали наук. конф., 15 трав. 2008 р. / ред. кол.: В.І. Борисов та ін. Харків : Право, 2008. С. 172-174.

3. Шевчук В.М. Наукові передумови та методологічні засади формування тактичнuх операиій у криміналістииі. Теорія та практика судової експертизи і криміналістики. 2017. Bun 17. C. 18-29.
4. Татарин Н.М., Пряхін Є.В. Методика розслідування самовільного зайняття земельної ділянки та самовільного будівниитва : монографія. Львів : ЛьвДУВС, 2019. $191 \mathrm{c}$.

5. Шевчук В.М. Проблеми функиіонального призначення тактичних операцій. Юридична осінь 2010 року : зб. тез доп. та наук. повідомл. учасн. Всеукр. наук.-пркт.конф. молодих учених та здобувачів, 23-24 листопада 2010 р. Харків, 2010. C. 161-164.

6. Шиканов В.И. Теоретические основы тактических операций в расследовании преступлений. Иркутск : Иркут. ун-т, 1983. 200 c.

7. Криминалистика: учебное пособие / А.В. Дулов и др. ; под ред. А.В. Дулова. Минск: Экоперспектива, 1996. 415 c.

8. Михальчук A.E. Тактические комбинации при производстве следственных действий / под ред. В.В. Степанова. Саратов : Capam. ун-m, 1991. 126 c.

9. Шевчук B.М. Тактичні операції у криміналістиці: теоретичні засади формування та практика реалізації : монографія. Харків : Anостіль, 2013. 440 c.

10. Шепітько В.Ю. Криміналістична тактика (системно-структурний аналіз) : монографія. Харків : Харків юридичний, 2007. 432 c.

11. Комаров И.М. Криминалистические операции в досудебном производстве : монография. Барнаул: Алт. ун-т, 2002. 346 с.

12. Шепитько В.Ю. Тактика расследования преступлений, совершаемых организованными группами и преступными организацииям. Харьков : Нац. юрид. акад. Украинь, 2000. $88 \mathrm{c}$.

13. Криминалистика : учебник / под ред. В.А. Образциова. Москва : Юристъ, 1995. $760 \mathrm{c}$.

14. Салтевський М.В. Криміналістика: підручник : у 2-х ч. Ч. 2. Харків : Консум, $2001.528 \mathrm{c}$

15. Шевчук В.М. Функиіональна спрямованість тактичних операцій. Вісник Академії правових наук України. 2010. № 4 (63). C. 240-249.

16. Шевчук В.М. Функиї тактичних операцій: наукові підходи, проблеми, перспективи. Питання боротьби зі злочинністю. 2010. Bun. 20. C. 202-213.

17. Шевчук B.M. Системний характер функцій тактичних операцій та їх класифікація. Теорія та практика судової експертизи і криміналістики. 2010. Bun. 10. C. 38-48. 


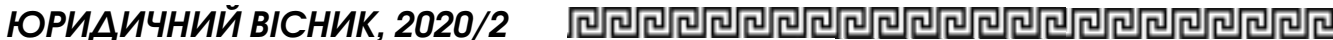

18. Коновалова В.О., Шепітько В.Ю. Юридична психологія : підручник ; 2-е вид., перероб. $i$ доп. Харків : Право, 2008. 208 с.

19. Лузгин И.М. Методологические проблемы расследования. Москва : Юрид. лит, 1973. $215 \mathrm{C}$

20. Методика розслідування окремих видів злочинів : навчальний посібник / O.I. Герасимів та ін. ; за заг. ред. Є.В. Пряхіна ; 2-е вид. перероб. $i$ доп. Львів : ЛьвДУВС, 2019. 312 c.

21. Самыгин Л.Д. Расследование преступлений как система деятельности. Москва : МГУ, 1989. 180 с.

22. Степанюк Р.Л., Заяиь Д.Д. Особливості порушення кримінальної справи про самовільне зайняття земельної ділянки та самовільне будівниитво. Вісник Харківського Національного університету внуmpiшнix справ. 2009. Bun. 44. C. 69-73.

23. Shepitko V., Spepitko M. Criminalistic strategy and trends in criminalistics. Criminalistic strategy and trends in criminalistics. Thematic Conference Proceedings of International Significance. Vol. 1 / International Scientific Conference "Archibald Reiss Days», Belgrade, 7-9 November 2017. P. 117-124.

24. Белкин Р.С. Криминалистика: проблеми сегодняшнего дня. Злободневные вопросы российской криминалистики. $M$ : НОРМА-ИНФА-М, 2001. $240 \mathrm{c}$.

25. Журавель В.А. Криміналістичні прогнози: форми та иляхи реалізащіі. Вісник Академії правових наук Харків. 2002. № 4 (31). C. 157-161.

26. Корноухов В.E. Методика расследования преступлении: теоретические основы. Москва: Норма, 2008. 224 с.

27. Протидія злочинам у сфері земельних відносин : навчальний посібник / C.В. Андрусенко та ін. ; за заг. ред. С.М. Гусарова. Харків : ХНУВС. 170 с.
28. Захарчук В.М. Самовільне зайняття земельної ділянки та самовільне будівниитво за кримінальним правом України : автореф. дис. ... канд. юрид. наук. Львів, 2014. $21 \mathrm{c}$.

29. Шевиук В.М. Організаційна спрямованість тактичних операцій. митна справа. 2014. № 2(92). С. 55-61.

30. Коновалова В.E. Организационные u психологические основы деятельности следователя. Киев : РИО МВД УССР, 1973. 22 c.

31. Шепітько В.Ю., Журавель В.А. Організаційно-тактичні засоби: поняття та значення. Питання боротьби зі злочинністю. 2009. Bun. 18. C. 185-192.

32. Коновалова В.Е. Версия: кониепция и функции в судопроизводстве. Харьков : Консум, 2000. 176 c.

33. Дякін Я.О. Типові версї у справах про злочини у сфері земельних відносин. Форум права. 2011. № 4. С. 240-246.

34. Криминалистика : учебник / отв. ред. Н.П. Яблоков ; 2-е изд., перераб. и доп. Москва: Юристь, 2001. 718 c.

35. Коновалова В.О., Шепітько В.Ю. Юридична психологія: академічний курс : підручник. Київ : Ін Юре, 2004. 424 с.

36. Тальянчук I.C. Криміналістична характеристика злочинів у сфері земельних відносин. Право та державне управління. 2013. № 1(10). С. 119-123.

37. Шевчук B.M. Тактична операція «Профілактика» під час розслідування митних злочинів. Митна справа. 2003. № 5. C. 59-69.

38. Шевчук В.М. Криміналістична профілактика злочинів та ї̈ роль у побудові методики розслідування: дискусійні проблеми. Вісник Академії правових наук України. 2002. № 2(29). С. 173-180. 